\title{
New Insights into Endocrine Pancreatic Development: The Role of Environmental Factors
}

\author{
M. Heinis M.T.Simon B. Duvillié \\ INSERM U845, Research Center Growth and Signalling, Université Paris Descartes, Faculté de Médecine, \\ Hôpital Necker, Paris, France
}

\section{Key Words}

Pancreas $\cdot \beta$-Cell $\cdot$ Development $\cdot$ Hypoxia .

Hypoxia-inducible factor $\cdot$ Nutrients $\cdot$ Transcription factors

\begin{abstract}
The pancreas is a mixed gland that contains endocrine and exocrine components. Within the pancreatic islets, $\beta$ cells produce insulin and control the glycemia. Their deficiency leads to diabetes and several potential complications. In the last decade, numerous studies have focused on pancreas development. The objective was to characterize the cellular and molecular factors that control the differentiation of endocrine and exocrine cell types. Investigation of the role of transcription factors by using genetic approaches led to the discovery of key molecules that are expressed both in rodents and humans. Some of them are ubiquitous, and some others are specifically involved in endocrine or exocrine specification. In addition to these intrinsic factors, recent studies have focused on the role of environmental factors. In the present review, we describe the roles of nutrients and oxygen in the embryonic pancreas. Interestingly, these extrinsic parameters can interfere with $\beta$-cell differentiation and function. Altogether, these data should help to generate $\beta$ cells in vitro and define strategies for a cell-based therapy of type 1 diabetes.

Copyright $\odot 2010$ S. Karger AG, Basel
\end{abstract}

\section{Introduction}

The pancreas is a mixed gland composed of endocrine and exocrine tissues. The endocrine fraction contains the islets of Langerhans, which include $\beta$ cells, $\alpha$ cells, $\delta$ cells, and PP cells that produce insulin, glucagon, somatostatin and pancreatic polypeptide, respectively. The exocrine fraction contains the acinar cells that release the digestive enzymes and the ductal cells. Diabetes mellitus arises from an inadequate mass of $\beta$ cells leading to hyperglycemia and a number of complications. Given the importance of $\beta$ cells to regulate the glycemia, many studies have focused on the development of $\beta$ cells $[1,2]$. The recent discoveries in this field should help defining protocols to derive $\beta$ cells in vitro and to progress towards a cell-based therapy of type 1 diabetes. The embryonic pancreas originates from the evagination of the endoderm both ventrally and dorsally. The two pancreatic buds will grow and fuse later to form a unique organ. During the last decades, the genetic network that controls pancreatic development has been well described (fig. 1) $[3,4]$. The pancreatic and duodenal homeobox 1 transcription factor (Pdxl) is expressed in all the pancreatic epithelial precursor cells. The deletion of Pdx1 in knockout animals led to a complete agenesis of the pancreas [5], showing the major importance of this factor. In humans, the homozygous

\section{KARGER \\ Fax +4161306 1234 E-Mail karger@karger.ch} www.karger.com
Dr. Bertrand Duvillié

U845 INSERM, Faculty Necker

156, rue de Vaugirard, FR-75015 Paris (France)

Tel. +331 406155 71, Fax +33143060443

E-Mail bertrand.duvillie@ inserm.fr 


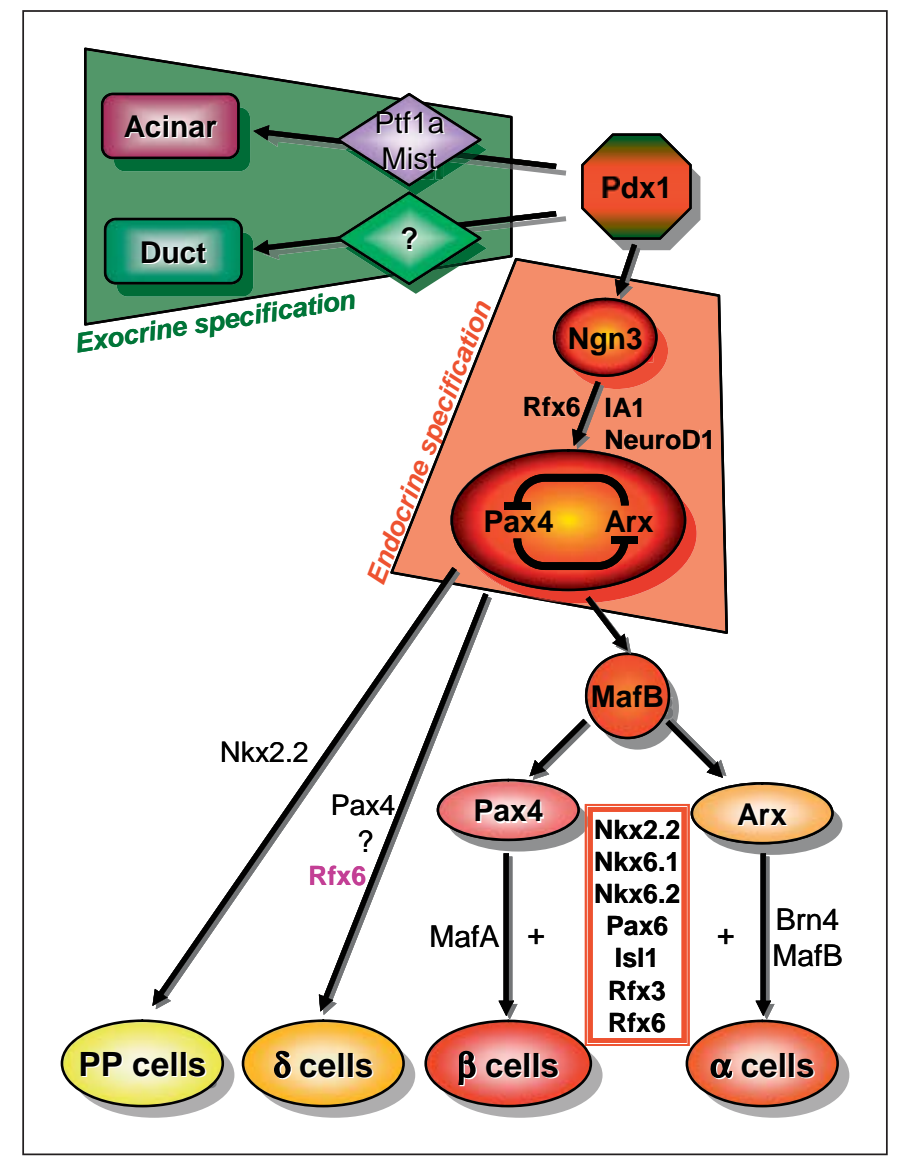

Fig. 1. Schematic representation of the hierarchy of transcription factors during pancreas development.

mutation of a single nucleotide in $P d x 1$ also resulted in the absence of the pancreas [6], showing that the role of $P d x 1$ is conserved between species. Other factors, the bHLH factors Ptfla, Hlxb9, and Isl1 are involved in the first steps of pancreas development. While p48-Ptfla and Mist1 control exocrine development, Hlxb9 and Isl1 are implicated in the initiation of the development of the dorsal pancreas [5, 7-9]. The transcription factor neurogenin 3 (Ngn3) is expressed after $P d x 1$ during development, in the cells that are committed to the endocrine lineages. The lack of Ngn3 in mice resulted in absence of endocrine differentiation [10]. Mellitzer et al. [11] showed that insulinoma-associated 1 (IA1), a zinc-finger containing factor, is activated by Ngn3 and controls endocrine development through the activation of a bHLH-containing factor, NeuroD1 (BETA2) [10-12]. In contrast to Ngn3-deficient mice, endocrine cells are present in NeuroD1 knockout mice, but they undergo massive apoptosis $[10,12]$. Pax4, a paired-box encoding gene, is expressed in the Ngn3-ex- pressing cells and is activated by Ngn3 [13]. Mice lacking Pax4 do not develop $\beta$ or $\delta$ cells [14]. Collombat el al. [15] showed that Arx, a member of the paired-like encoding gene family, and Pax4 are mutually antagonistically regulated. Pax4 favors $\beta$ - and $\delta$-cell commitment while Arx favors $\alpha$-cell commitment [15]. MafA and MafB belong to the large Maf family of leucine zipper (bZIP) transcription factors. Nishimura et al. [16] showed that $\alpha$ - and $\beta$-cell differentiation occurs from a precursor expressing MafB. Their results suggest that differentiation of $\beta$ cells proceeds through a MafB+MafA-Ins+ intermediate cell to MafB-MafA+Ins+ cells. The expression pattern of MafB reveals a role of MafB in both $\alpha$ - and $\beta$-cell development. Other factors, like the POU homeobox transcription factor 4 brain 4/POU3F4, are expressed in glucagon-expressing cells. Some Brn4+ cells co-express Pax6 and Isl1. Later, its expression is restricted to $\alpha$ cells, suggesting that Brn4 is a marker of the $\alpha$ cells' progenitors [17]. Nkx2.2, Nkx6.1 and Nkx6.2 belong to the NKX protein family. They are involved in endocrine development $[18,19]$. Nkx2.2 is expressed in the progenitors during early development and becomes restricted to some Ngn3-positive cells during embryogenesis and next to $\alpha, \beta$, and PP cells. In Nkx2. 2 mutant mice, $\beta$ cells are absent and numbers of $\alpha$ and PP cells are decreased $[18,19]$. Nkx6.1 is first expressed in the pancreatic epithelium at E10.5. Next its expression is restricted to the Ngn3-expressing cells, and is found later exclusively in the adult $\beta$ cells [19]. Nkx6.2 is expressed in the undifferentiated epithelium and is restricted to acinar and $\alpha$ cells at E15.5, but is excluded from Ngn3-positive cells [19]. Inactivation of Nkx6.1 leads to reduced $\beta$-cell mass [20]. In the absence of Nkx6.2, the development of the pancreas remains normal. However, Nkx6.1-/-Nkx6.2-/- mice display reduced numbers of $\beta$ and $\alpha$ cells [20], showing the importance of Nkx6.2. In order to compare the role of transcription factors in rodents and human, Lyttle et al. [21] analyzed the transcriptome of the human fetal pancreas at different stages. In the human fetal pancreas, Ngn3 is expressed in early development. Q-PCR analyses showed a decrease of Ngn3 expression as development progressed from 8 to 21 weeks. Moreover, microarray experiments revealed that Isl1, NeuroD1, MafB, and Pax6 were significantly increased during human fetal pancreas development whereas Pax4, Nkx2.2, and Nkx6.1 were expressed but remained constant [21]. Recently, microarray analysis has investigated the genes expressed in E15.5 eYFP-Ngn3-positive cells versus Ngn3negative cells. Interestingly, the Rfx6 factor, which belongs to the Rfx transcription factor family, was enriched in the Ngn3-positive cells [22]. Rfx6 is expressed in Pdx1- 
expressing cells within the pancreatic buds and becomes restricted to the endocrine cell types [22]. Expression of Rfx6 was unaffected in Arx-, Pax4-, and NeuroD1-deficient mice, suggesting that Rfx6 acts downstream of Ngn3 and upstream of Arx, Pax4 and NeuroD1 [22]. Interestingly, mice lacking Rfx6 failed to generate any of the normal islet cell types except for the pancreatic polypetideproducing cells [23]. In human infants with a similar autosomal recessive syndrome of neonatal diabetes, genetic mapping and subsequent sequencing identified mutations in the human Rfx6 gene [23]. Another gene of the same family, Rfx3, is expressed in the Ngn3-positive cells, and is found in the developing and mature islet cells. Rf 3 is involved in the growth and function of cilia. Before birth, $\mathrm{Rf} \times 3-/-$ islets contain reduced numbers of $\alpha$ and $\beta$ cells whereas the number of PP cells is increased. In adult mice, the lack of Rfx3 leads to small and disorganized islets, with reduced insulin production and impaired glucose tolerance [24]. These data underline the sequential intervention of the transcription factors during the decisions of cell commitment in the pancreas development.

The complexity of the genetic network is modulated by the signals provided by the surrounding tissues and also by environmental parameters. The roles of notochord, blood vessels and epithelio-mesenchymal interactions in pancreas development were previously documented [25-28]. Mechanical stresses generated by cell growth also participate to organogenesis [29]. In this review, we focus on the roles of nutrients [30] and oxygen.

\section{Role of Nutrients}

Low birth weight is an important risk for type 2 diabetes in later life. Both maternal environment and the fetal genome influence the number and function of the $\beta$ cells in early life and this has lifelong implications for postnatal diabetes [31]. During the past decade, numerous studies have focused on the role of nutrients on pancreas development [32-38]. Indeed, adverse events that include modifications of the diet during early life may affect the growth of different organs and cause metabolic disorders in later life. Recently, Dumortier et al. [35] exposed pregnant rats to low protein or low energy diet during different windows of gestation. The low energy diet decreased the $\beta$ cell mass in 21 -day-old fetuses by 33 or $56 \%$ when administered during the last week or throughout gestation, respectively. Fetal corticosterone was increased. The poor development of $\beta$-cell mass was correlated with a decrease of the number of NGN3 - and Pdx1-expressing cells, show- ing an effect of this diet on neogenesis. The low protein diet also induced a reduction of the $\beta$-cell mass but this effect was more pronounced when applied during the last week of gestation $(-53 \%)$ than throughout gestation $(-33 \%)$. This diet altered $\beta$-cell proliferation and islet vascularization but not the expression of NGN3 or PDX1 [35]. Altogether, these data demonstrate that the diet controls $\beta$-cell development. One explanation for the effects of the low energy diet could be the increase of corticosterone. Indeed, previous studies showed that overexposure to glucocorticoids in utero mediates the effects of undernutrition on the $\beta$-cell mass [39]. Exposure of pregnant rats to low protein diet also causes impaired glucose homeostasis in the young adult offspring [40]. Dietary insult in early life is thus able to affect the development and future function of the endocrine pancreas. Surprisingly, the diet during gestation can also influence the onset of type 1 diabetes. When non-obese diabetic mice were exposed to low protein diet during early life, the onset of diabetes was delayed [41]. Indeed, low protein diet throughout gestation led to decreased levels of cytotoxic cytokines and reduced insulitis. In females, low protein diet was also associated with a reduction of the number and size of the pancreatic islets, lower insulin pancreatic content and lower serum insulin. However, the ability of low protein diet to delay the onset of diabetes was sex-independent. The mechanism by which low protein diet delays the onset of diabetes is likely to involve both immune alterations and changes in $\beta$-cell development [41]. A human correlate of such observation could be the lower incidence of type 1 diabetes seen in individuals born of low birth weight or subjected to nutritional deficiencies [42, 43].

More recently, Guillemain et al. [44, 45] also examined the effects of glucose levels in endocrine differentiation. They found that glucose interferes with the pancreatic endocrine cells development by regulating the transition between Ngn3 and NeuroD [45]. Moreover, glucose activates $\beta$-cell development in vitro in a dose-dependent manner [45]. Altogether, these data should increase our control on the regimens during pregnancy that could impact on the occurrence of type 1 and type 2 diabetes.

\section{Oxygen and $\beta$-Cell Development}

At low oxygen tension $\left(\mathrm{pO}_{2}\right)$, cells undergo adaptative changes, including increased angiogenesis and erythropoiesis, and a switch to glycolytic metabolism. The cellular response to hypoxia is tightly controlled by the hypoxiainducible factor (HIF) complex. HIF is regulated in an $\mathrm{O}_{2^{-}}$ 


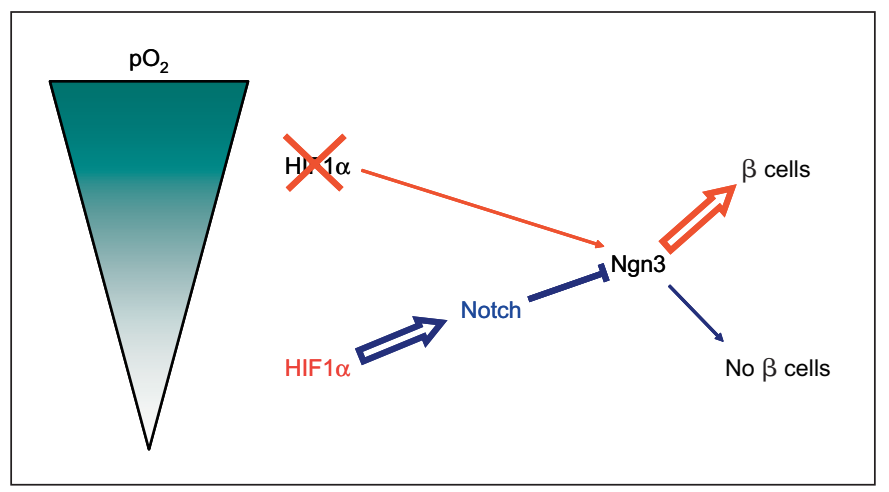

Fig. 2. Representative model of the effects of oxygen $\left(\mathrm{pO}_{2}\right)$ on $\beta$ cell differentiation. In the presence of high levels of oxygen, the PHD are active, HIF $1 \alpha$ is modified. Next, HIF $1 \alpha$ is degraded by the proteasome. Expression of $\mathrm{Ngn} 3$ precedes the differentiation of $\beta$ cells. In hypoxia, PHD activity is reduced and HIF1 $\alpha$ is stabilized. The Notch pathway is activated, Ngn3 expression is repressed and $\beta$ cells develop poorly.

dependent manner by hydroxylation of one of the three $\mathrm{HIF} \alpha$ subunits (HIF1 $\alpha, \mathrm{HIF} 2 \alpha, \mathrm{HIF} 3 \alpha$ ). In normoxia, hydroxylation of the proline HIFl $\alpha$ residues by prolyl hydroxylases (PHD) leads to recognition and polyubiquitinylation by the von Hippel-Lindau (VHL) E3 ligase complex, leading to proteasomal degradation of HIF1 $\alpha$. On the other hand, in the hypoxic state, prolyl hydroxylase activity is decreased and HIF1 $\alpha$ is stabilized. During embryogenesis, cell oxygenation levels vary widely. In general, $\mathrm{pO}_{2}$ occurs naturally at low levels in the embryos. Partial pressure of oxygen is generally detected in the tissues in a range from 2 to $9 \%$ of the atmospheric pressure, and is even lower levels in tissues such as kidney medulla, bone marrow or thymus [46]. Recent investigations of the role of hypoxia and HIF1 $\alpha$ during development of several organs showed that hypoxia decreases the differentiation of neural precursor cells, myogenic cells, adipocytes, and endothelial cells in a HIF1 $\alpha$-dependent manner. In the pancreas, recent studies have indicated that HIF $1 \alpha$ has a role in the secretion of insulin in response to glucose [47-49]. However, the role of HIF1 $\alpha$ in the early steps of $\beta$-cell development remain to be investigated.

Recently, we described the expression pattern of HIF $1 \alpha$ in the rat pancreas. At early stages of embryogenesis (E11.5-E13.5), HIF1 $\alpha$ was found in the precursor cells that expressed PDX1. Later, HIF1 $\alpha$ protein expression decreased and was not expressed in the differentiated endocrine cells [50]. HIF2 $\alpha$ was absent in the embryonic pancreas. In order to define the role of the partial pressure of oxygen in $\beta$-cell differentiation, we compared cultures of pancreases in hypoxia versus normoxia. When compared to normoxia, we found that hypoxia induced the stabilization of HIF1 $\alpha$, a dramatic reduction of $\mathrm{Ngn} 3$ expression as well as a reduced $\beta$-cell differentiation [50]. To determine the exact role of HIF $1 \alpha$ in $\beta$-cell differentiation, we forced HIF1 $\alpha$ stabilization by using PHD inhibitors. This treatment mimicked the effects of hypoxia on pancreas development. Indeed, upon PHD inhibition, Ngn3 expression and $\beta$-cell differentiation were reduced as compared to controls. Interestingly, this effect was mediated by a HIF1 $\alpha$-dependent Notch pathway (fig. 2) [50]. The interaction between the oxygen (HIFl $\alpha$ ) pathway and the Notch pathway also occurs during neural and myogenic differentiation [51]. Similarly, in the endothelial progenitors, hypoxia induces the Notch pathway by activating the Dll4-Notch-Hey2 pathway and also represses the expression of the differentiation marker COUPTFII [52], suggesting that a more general mechanism could be involved. Altogether, these data demonstrate that hypoxia is a limiting parameter for $\beta$-cell development. Other laboratories using different culture systems also reported the importance of oxygen for pancreas development $[53,54]$. Indeed, Fraker et al. found that enhanced oxygenation of the tissues in vitro could promote $\beta$-cell differentiation. Such findings support our hypothesis. Moreover, in the limb bud, the condensation of mesenchyme is similar to the anatomy of the embryonic pancreas and this condensation generates hypoxia that leads to HIF stabilization. The central role of HIF1 $\alpha$ limb development was recently demonstrated in knockout animals [55], indicating that hypoxia has a physiological role in several organs including the pancreas during embryogenesis.

\section{HIF and the $\beta$-Cell Function}

The HIF complex is an $\alpha / \beta$ heterodimer. Although HIF1 $\alpha$ is sensitive to the level of oxygen, HIF1 $\beta$, also called ARNT, is constitutively expressed. The possible role of ARNT in the $\beta$ cells was examined. $\beta$-Cell specific knockout of ARNT in mice led to abnormal glucose tolerance and impaired insulin secretion [56]. Interestingly, microarrays analysis in pancreatic islets from type 2 diabetic patients showed a $90 \%$ reduction of ARNT when compared to human glucose tolerant islets, showing that in addition to its physiological role, ARNT may be involved in the pathogenesis of type 2 diabetes [56].

The VHL protein controls the degradation of HIF1 $\alpha$. In mice lacking VHL in $\beta$ cells, HIF1 $\alpha$ was stabilized in the islets, and a defect of glucose-stimulated insulin se- 
cretion was observed [47-49]. The deletion of HIF $1 \alpha$ in $\beta$ cells restored a normal insulin secretion in response to glucose in these mice, indicating that the abnormal glucose homeostasis was dependent on HIF1 $\alpha$ upregulation [47]. HIF1 $\alpha$ induces the expression of the high-affinity glucose transporter GLUT1 and glycolytic enzymes, and decreases mitochondrial oxygen consumption [57]. Since glucose uptake, glycolysis and mitochondrial respiration have a major role in glucose sensing, these effects of the HIF pathway might be involved in the impaired stimulated insulin secretion that occurs in the VHL knockout mice. Interestingly, Cantley et al. [47] found that islets lacking VHL in the $\beta$ cells have impaired glucose uptake, altered mitochondrial metabolism, and the glucose-stimulated flux of $\mathrm{Ca}^{2+}$ was attenuated as compared to controls, supporting this hypothesis. Altogether, these data demonstrate that the oxygen (HIF) pathway plays an important role in $\beta$ cells, and can impact on their function when hypoxia occurs.

In conclusion, recent data shed light on the roles of environmental factors, as nutrients and oxygen, on the de- velopment and the function of $\beta$ cells. We think that understanding the cellular and molecular mechanisms that control endocrine differentiation should help to generate $\beta$ cells in vitro and to improve the protocols for a cellbased therapy of type 1 diabetes. Moreover, an association of HIFl $\alpha$ gene polymorphism with type 1 and type 2 diabetes was discovered recently [58]. The characterization of the role of oxygen/HIF in diabetes should render possible the use of molecules that interfere with this pathway and facilitates the function of $\beta$ cells.

\section{Acknowledgments}

M.H. received support from the French Ministry for Research and Technology, and from the Association pour la Recherche contre le Cancer (ARC). This work was supported by an Alfediam/ Sanofi-Aventis grant (B.D.), EFSD/NovoNordisk grant (B.D.), the National Institutes of Health Beta Cell Biology Consortium (DK 072495-02) (Raphael Scharfmann), the 6th European Union Framework Program (Beta-Cell Therapy Integrated Project) (R.S.), and the Association Française des Diabetiques (R.S.).

\section{References}

1 Duvillie B, Stetsyuk V, Filhoulaud G, Guillemain G, Scharfmann R: Control of pancreatic development by intercellular signals. Biochem Soc Trans 2008;36:276-279.

-2 Scharfmann R, Duvillie B, Stetsyuk V, Attali M, Filhoulaud G, Guillemain G: Betacell development: the role of intercellular signals. Diabetes Obes Metab 2008;10(suppl 4):195-200

-3 Bonal C, Herrera PL: Genes controlling pancreas ontogeny. Int J Dev Biol 2008;52:823835 .

-4 Collombat P, Hecksher-Sorensen J, Serup P, Mansouri A: Specifying pancreatic endocrine cell fates. Mech Dev 2006;123:501-512.

5 Ahlgren U, Jonsson J, Edlund H: The morphogenesis of the pancreatic mesenchyme is uncoupled from that of the pancreatic epithelium in IPF1/PDX1-deficient mice. Development 1996;122:1409-1416.

-6 Stoffers DA, Zinkin NT, Stanojevic V, Clarke WL, Habener JF: Pancreatic agenesis attributable to a single nucleotide deletion in the human IPF1 gene coding sequence. Nat Genet 1997;15:106-110

7 Pin CL, Rukstalis JM, Johnson C, Konieczny SF: The bHLH transcription factor Mistl is required to maintain exocrine pancreas cell organization and acinar cell identity. J Cell Biol 2001;155:519-530.
8 Krapp A, Knofler M, Ledermann B, Burki K, Berney C, Zoerkler N, Hagenbuchle O, Wellauer PK: The bHLH protein Ptf1-p48 is essential for the formation of the exocrine and the correct spatial organization of the endocrine pancreas. Genes Dev 1998;12: 3752-3763.

-9 Li H, Arber S, Jessell TM, Edlund H: Selective agenesis of the dorsal pancreas in mice lacking homeobox gene Hlxb9. Nat Genet 1999;23:67-70

$\checkmark 10$ Gradwohl G, Dierich A, LeMeur M, Guillemot F: Neurogenin-3 is required for the development of the four endocrine cell lineages of the pancreas. Proc Natl Acad Sci USA 2000;97:1607-1611.

11 Mellitzer G, Bonne S, Luco RF, Van De Casteele M, Lenne-Samuel N, Collombat P, Mansouri A, Lee J, Lan M, Pipeleers D, Nielsen FC, Ferrer J, Gradwohl G, Heimberg $\mathrm{H}$ : IA1 is NGN3-dependent and essential for differentiation of the endocrine pancreas. EMBO J 2006;25:1344-1352.

12 Naya FJ, Huang HP, Qiu Y, Mutoh H, DeMayo FJ, Leiter AB, Tsai MJ: Diabetes, defective pancreatic morphogenesis, and abnormal enteroendocrine differentiation in BETA2/neuroD-deficient mice. Genes Dev 1997;11:2323-2334.

13 Smith SB, Ee HC, Conners JR, German MS Paired-homeodomain transcription factor PAX4 acts as a transcriptional repressor in early pancreatic development. Mol Cell Biol 1999;19:8272-8280
14 Sosa-Pineda B, Chowdhury K, Torres M, Oliver G, Gruss P: The Pax4 gene is essential for differentiation of insulin-producing $\beta$ cells in the mammalian pancreas. Nature 1997; 386:399-402.

15 Collombat P, Mansouri A, Hecksher-Sorensen J, Serup P, Krull J, Gradwohl G, Gruss P: Opposing actions of Arx and Pax4 in endocrine pancreas development. Genes Dev 2003:17:2591-2603.

16 Nishimura W, Kondo T, Salameh T, El Khattabi I, Dodge R, Bonner-Weir S, Sharma A: A switch from MafB to MafA expression accompanies differentiation to pancreatic $\beta$ cells. Dev Biol 2006;293:526-539.

17 Heller RS, Stoffers DA, Liu A, Schedl A, Crenshaw EB 3rd, Madsen OD, Serup P: The role of Brn4/Pou3f4 and Pax6 in forming the pancreatic glucagon cell identity. Dev Biol 2004;268:123-134.

$\rightarrow 18$ Sussel L, Kalamaras J, Hartigan-O’Connor DJ, Meneses JJ, Pedersen RA, Rubenstein JL, German MS: Mice lacking the homeodomain transcription factor $\mathrm{Nkx} 2.2$ have diabetes due to arrested differentiation of pancreatic $\beta$ cells. Development 1998;125: 2213-2221.

- 19 Sander M, Sussel L, Conners J, Scheel D, Kalamaras J, Dela Cruz F, Schwitzgebel V, Hayes-Jordan A, German M: Homeobox gene Nkx6.1 lies downstream of Nkx2.2 in the major pathway of $\beta$-cell formation in the pancreas. Development 2000;127:55335540 . 
20 Henseleit KD, Nelson SB, Kuhlbrodt K, Hennings JC, Ericson J, Sander M: NKX6 transcription factor activity is required for $\alpha$ and $\beta$-cell development in the pancreas. Development 2005;132:3139-3149.

-21 Lyttle BM, Li J, Krishnamurthy M, Fellows F, Wheeler MB, Goodyer CG, Wang R: Transcription factor expression in the developing human fetal endocrine pancreas. Diabetologia 2008;51:1169-1180.

-22 Soyer J, Flasse L, Raffelsberger W, Beucher A Orvain C, Peers B, Ravassard P, Vermot J, Voz ML, Mellitzer G, Gradwohl G: Rfx6 is an Ngn3-dependent winged helix transcription factor required for pancreatic islet cell development. Development 2010;137:203-212.

23 Smith SB, Qu HQ, Taleb N, Kishimoto NY, Scheel DW, Lu Y, Patch AM, Grabs R, Wang J, Lynn FC, Miyatsuka T, Mitchell J, Seerke R, Desir J, Eijnden SV, Abramowicz M, Kacet N, Weill J, Renard ME, Gentile M, Hansen I, Dewar K, Hattersley AT, Wang R, Wilson ME, Johnson JD, Polychronakos C, German MS: Rfx6 directs islet formation and insulin production in mice and humans. Nature 463: 775-780.

-24 Ait-Lounis A, Baas D, Barras E, Benadiba C, Charollais A, Nlend Nlend R, Liegeois D, Meda P, Durand B, Reith W: Novel function of the ciliogenic transcription factor RFX3 in development of the endocrine pancreas. Diabetes 2007;56:950-959.

- 25 Lammert E, Cleaver O, Melton D: Induction of pancreatic differentiation by signals from blood vessels. Science 2001;294:564-567.

-26 Li Z, Manna P, Kobayashi H, Spilde T, Bhatia A, Preuett B, Prasadan K, Hembree M, Gittes GK: Multifaceted pancreatic mesenchymal control of epithelial lineage selection. Dev Biol 2004;269:252-263.

-27 Miralles F, Czernichow P, Ozaki K, Itoh N, Scharfmann R: Signaling through fibroblast growth factor receptor $2 \mathrm{~b}$ plays a key role in the development of the exocrine pancreas. Proc Natl Acad Sci USA 1999;96:6267-6272.

-28 Duvillie B, Attali M, Bounacer A, Ravassard P, Basmaciogullari A, Scharfmann R: The mesenchyme controls the timing of pancreatic $\beta$-cell differentiation. Diabetes 2006;55: 582-589.

-29 Nelson CM, Jean RP, Tan JL, Liu WF, Sniadecki NJ, Spector AA, Chen CS: Emergent patterns of growth controlled by multicellular form and mechanics. Proc Natl Acad Sci USA 2005;102:11594-11599.

- 30 Breant B, Gesina E, Blondeau B: Nutrition, glucocorticoids and pancreas development. Horm Res 2006;65(suppl 3):98-104.

- 31 Hill DJ, Duvillie B: Pancreatic development and adult diabetes. Pediatr Res 2000;48:269274.

-32 Arany E, Strutt B, Romanus P, Remacle C, Reusens B, Hill DJ: Taurine supplement in early life altered islet morphology, decreased insulitis and delayed the onset of diabetes in non-obese diabetic mice. Diabetologia 2004; 47:1831-1837.
33 Armitage JA, Taylor PD, Poston L: Experimental models of developmental programming: consequences of exposure to an energy rich diet during development. J Physiol 2005;565:3-8.

34 Boujendar S, Arany E, Hill D, Remacle C, Reusens B: Taurine supplementation of a low protein diet fed to rat dams normalizes the vascularization of the fetal endocrine pancreas. J Nutr 2003;133:2820-2825.

35 Dumortier O, Blondeau B, Duvillie B, Reusens B, Breant B, Remacle C: Different mechanisms operating during different critical time-windows reduce rat fetal $\beta$ cell mass due to a maternal low-protein or lowenergy diet. Diabetologia 2007;50:24952503.

36 Garofano A, Czernichow P, Breant B: Impaired $\beta$-cell regeneration in perinatally malnourished rats: a study with STZ. FASEB J 2000;14:2611-2617.

37 Petrik J, Reusens B, Arany E, Remacle C, Coelho C, Hoet JJ, Hill DJ: A low protein diet alters the balance of islet cell replication and apoptosis in the fetal and neonatal rat and is associated with a reduced pancreatic expression of insulin-like growth factor II. Endocrinology 1999;140:4861-4873.

38 Petrik J, Srinivasan M, Aalinkeel R, Coukell S, Arany E, Patel MS, Hill DJ: A long-term high-carbohydrate diet causes an altered ontogeny of pancreatic islets of Langerhans in the neonatal rat. Pediatr Res 2001;49:84-92.

39 Blondeau B, Lesage J, Czernichow P, Dupouy JP, Breant B: Glucocorticoids impair fetal $\beta$ cell development in rats. Am J Physiol 2001; 281:E592-E599.

40 Chamson-Reig A, Thyssen SM, Hill DJ, Arany E: Exposure of the pregnant rat to low protein diet causes impaired glucose homeostasis in the young adult offspring by different mechanisms in males and females. Exp Biol Med (Maywood) 2009;234:1425-1436.

41 Chamson-Reig A, Arany EJ, Summers K, Hill DJ: A low protein diet in early life delays the onset of diabetes in the non-obese diabetic mouse. J Endocrinol 2009;201:231-239.

42 Fronczak CM, Baron AE, Chase HP, Ross C, Brady HL, Hoffman M, Eisenbarth GS, Rewers M, Norris JM: In utero dietary exposures and risk of islet autoimmunity in children. Diabetes Care 2003;26:3237-3242.

43 Dahlquist G, Bennich SS, Kallen B: Intrauterine growth pattern and risk of childhood onset insulin-dependent (type 1) diabetes: population-based case-control study. BMJ 1996;313:1174-1177.

-44 Filhoulaud G, Guillemain G, Scharfmann R The hexosamine biosynthesis pathway is essential for pancreatic $\beta$-cell development. J Biol Chem 2009;284:24583-24594.

45 Guillemain G, Filhoulaud G, Da Silva-Xavier G, Rutter GA, Scharfmann R: Glucose is necessary for embryonic pancreatic endocrine cell differentiation. J Biol Chem 2007;282: 15228-15237.

46 Simon MC, Keith B: The role of oxygen availability in embryonic development and stem cell function. Nat Rev Mol Cell Biol 2008;9: 285-296.
47 Cantley J, Selman C, Shukla D, Abramov AY, Forstreuter F, Esteban MA, Claret M, Lingard SJ, Clements M, Harten SK, AsareAnane H, Batterham RL, Herrera PL, Persaud SJ, Duchen MR, Maxwell PH, Withers DJ: Deletion of the von Hippel-Lindau gene in pancreatic $\beta$ cells impairs glucose homeostasis in mice. J Clin Invest 2009;119:125135.

48 Puri S, Cano DA, Hebrok M: A role for von Hippel-Lindau protein in pancreatic $\beta$-cell function. Diabetes 2009;58:433-441.

49 Zehetner J, Danzer C, Collins S, Eckhardt K, Gerber PA, Ballschmieter P, Galvanovskis J, Shimomura K, Ashcroft FM, Thorens B, Rorsman P, Krek W: PVHL is a regulator of glucose metabolism and insulin secretion in pancreatic $\beta$ cells. Genes Dev 2008;22:31353146.

50 Heinis M, Simon MT, Ilc K, Mazure N, Pouyssegur J, Scharfmann R, Duvillie B: Oxygen tension regulates pancreatic $\beta$-cell differentiation through HIF1 $\alpha$. Diabetes 2010; 59:662-669.

51 Gustafsson MV, Zheng X, Pereira T, Gradin K, Jin S, Lundkvist J, Ruas JL, Poellinger L, Lendahl U, Bondesson M: Hypoxia requires notch signaling to maintain the undifferentiated cell state. Dev Cell 2005;9:617-628.

52 Diez H, Fischer A, Winkler A, Hu CJ, Hatzopoulos AK, Breier G, Gessler M: Hypoxiamediated activation of Dll4-Notch-Hey2 signaling in endothelial progenitor cells and adoption of arterial cell fate. Exp Cell Res 2007;313:1-9.

53 Fraker CA, Ricordi C, Inverardi L, Dominguez-Bendala J: Oxygen: a master regulator of pancreatic development? Biol Cell 2009; 101:431-440

-54 Fraker CA, Alvarez S, Papadopoulos P, Giraldo J, Gu W, Ricordi C, Inverardi L, Dominguez-Bendala J: Enhanced oxygenation promotes $\beta$-cell differentiation in vitro. Stem Cells 2007;25:3155-3164.

55 Provot S, Zinyk D, Gunes Y, Kathri R, Le Q, Kronenberg HM, Johnson RS, Longaker MT, Giaccia AJ, Schipani E: HIF-1 $\alpha$ regulates differentiation of limb bud mesenchyme and joint development. J Cell Biol 2007;177:451464

56 Gunton JE, Kulkarni RN, Yim S, Okada T, Hawthorne WJ, Tseng YH, Roberson RS, Ricordi C, O'Connell PJ, Gonzalez FJ, Kahn CR: Loss of ARNT/HIF1 $\beta$ mediates altered gene expression and pancreatic-islet dysfunction in human type 2 diabetes. Cell 2005; 122:337-349.

57 Kaelin WG: Proline hydroxylation and gene expression. Annu Rev Biochem 2005; 74:115128.

58 Nagy G, Kovacs-Nagy R, Kereszturi E, Somogyi A, Szekely A, Nemeth N, Hosszufalusi N, Panczel P, Ronai Z, Sasvari-Szekely $\mathrm{M}$ : Association of hypoxia-inducible factor$1 \alpha$ gene polymorphism with both type 1 and type 2 diabetes in a Caucasian (Hungarian) sample. BMC Med Genet 2009;10:79. 